\title{
Expropriations of Private Property for Economic 'Development' in the United States: Re-Thinking the Titling and Rule of Law Solutions to Land Grabs in the Global South
}

\author{
Expropiaciones para el 'desarrollo' económico en los EE.UU.: \\ repensar la titulación y el imperio de la ley como soluciones \\ al despojo de tierras en el Sur global \\ Expropriações para o 'desenvolvimento' econômico nos EUA: \\ repensar a titulação e o império da lei como soluções de despojo \\ de terras no Sul global
}

FRANCES THOMSON ${ }^{*}$

FECHA DE RECEPCIÓN: 29 DE ABRIL DE 2019. FECHA DE APROBACIÓN: 18 DE OCTUBRE DE 2019

Doi: https://doi.org/10.12804/revistas.urosario.edu.co/sociojuridicos/a.7872

To cite this article: Thomson, F. (2020). Expropriations of private property for economic 'development' in the United States: re-thinking the titling and rule of law solutions to land grabs in the global South. Estudios Socio-Jurídicos, 22(2), 209-239. Doi: https://doi.org/10.12804/revistas.urosario.edu.co/sociojuridicos/a.7872

\begin{abstract}
Mainstream discourses tend to treat land dispossession as a 'developing' country problem that arises due to weak/corrupt legal systems and inadequate property institutions. This article unsettles such discourses by examining expropriations for economic 'development' in the United States - a country typically deemed to have strong property institutions and a strong rule of law. Drawing on various examples, I propose that expropriation in the US is neither rigorously conditional nor particularly exceptional. While most 'takings' laws are supposed to restrict the State's power, this restriction hinges on the definition of
\end{abstract}

* Researcher at The University of London - SOAS in the United Kingdom. This article was written as part of my doctoral research at the University of Sussex - Centre for Global Political Economy and is based on a paper I presented at the 2016 Tierras $y$ territorios conference held at the Universidad Externado, Colombia. I would like to thank the United Kingdom Economic and Social Research Council (ESRC) and the University of Sussex for funding my doctoral research (award number: ES/J500173/1), the various reviewers who provided comments on different versions of this paper, and my supervisors: Lara Coleman and Ben Selwyn for their support and advice. Email: ft12@soas.ac.uk. ORCID: 0000-0001-7048-5160 
public use, purpose, necessity, or interest. And in many countries, including the US, these concepts are now defined broadly and vaguely so as to include private for-profit projects. Ultimately, the contents, interpretation, and application of the law are subject to social and political struggles; this point is habitually overlooked in the rule of law 'solutions' to land grabbing-. For these reasons, titling/registration programs and policies aimed at strengthening the rule of law, even if successful, are likely to transform rather than 'solve' dispossession in the global South.

Keywords: Expropriation, private property, dispossession, land grabbing, United States.

\section{RESUMEN}

Los discursos dominantes tienden a tratar el despojo de tierras como un problema de los países 'en desarrollo', derivado de sistemas legales débiles/corruptos e instituciones de propiedad inadecuadas. Este artículo desestabiliza esos discursos al examinar casos de expropiación en Estados Unidos (EE. UU.) - país al que normalmente se le considera con instituciones de propiedad robustas y un sólido estado de derecho-. Con base en varios ejemplos, argumento que las expropiaciones en EE. UU. no son rigurosamente condicionadas ni particularmente excepcionales. Si bien la mayoría de las leyes de expropiación supuestamente restringen los poderes del Estado, esta restricción depende de la definición del uso, propósito, necesidad o interés público; además, en muchos países, incluido EE. UU., estos términos son definidos de manera amplia y vaga para así incluir proyectos privados con fines de lucro. En últimas, los contenidos, la interpretación y la aplicación de la ley están sujetos a luchas sociales y políticas - punto que suele ser pasado por alto en las 'soluciones' convencionales al despojo-. Por estas razones, los programas de titulación y las políticas dirigidas al fortalecimiento del estado de derecho (aun cuando sean exitosas) puede que transformen, más que resuelvan, el despojo en el Sur global.

Palabras clave: expropiación, propiedad privada, despojo de tierras, Estados Unidos.

\section{RESUMO}

Os discursos dominantes tendem a tratar o despojo de terras como um problema dos países 'em desenvolvimento', derivado de sistemas legais fracos/corruptos e instituições de propriedade inadequadas. Este artigo desestabiliza esses discursos ao examinar casos de expropriação nos Estados Unidos - país ao que normalmente considera-se lhe com instituições de propriedade robustas e um sólido estado de direito-. Com base em vários exemplos, argumento que as expropriações nos EUA não são rigorosamente condicionadas, nem particularmente excepcionais. Ainda que a maior parte das leis de expropriação supostamente restringem os poderes do Estado, esta restrição depende da definição do uso, propósito, necessidade ou interesse público; e em muitos países, incluídos os EUA, estes termos são definidos de maneira ampla e vaga, para assim incluir projetos privados com fins lucrativos. Finalmente, os conteúdos, a interpretação e a aplicação da lei estão sujeitos a lutas sociais e políticas - ponto que pode ser ignorado nas 'soluções' convencionais de despojo-. Por estes motivos, os programas de titulação e as políticas dirigidas ao fortalecimento do estado de direito (ainda quando sejam bem-sucedidas) pode que transformem, mais do que 'resolver', o despojo no Sul global.

Palavras-chave: expropriação, propriedade privada, despojo de terras, Estados Unidos. 


\section{Introduction}

Expropriation, or the forcible taking of private property by the State, is often associated with authoritarian or socialist regimes that garner support for redistributive policies; this association is reinforced by mainstream media, which tends to focus on instances affecting large firms and foreign investors. ${ }^{1}$ Nevertheless, liberal democratic governments with capitalist market economies also expropriate for diverse ends -most notably to make way for private investments alleged to bolster economic development- and the expropriated are commonly 'ordinary' people rather than big companies. In this sense and given that the less powerful are habitually under-compensated for their homes/land, expropriations frequently entail a regressive redistribution of wealth. This is the type of expropriation that interests me in this article, which focuses on the United States (US).

Expropriation became a central theme in the 2016 US presidential primaries ( $A B C$ News, 2016; NPR, 2016). Donald Trump was characteristically uninhibited in his assessment: "The Key Stone pipeline without eminent domain [government power to expropriate], it wouldn't go ten feet. [...] You wouldn't have massive factories without eminent domain" (cited in: $A B C$ News, 2016). In an earlier interview, he stated plainly: "You need eminent domain. It's called economic development" (cited in: Fox News, 2015). He also said he agreed $100 \%$ with the Us Supreme Court's controversial decision in the 2005 Kelo vs. New London case, which sanctioned expropriation in a wide variety of circumstances. It is noteworthy that a Republican (US Republicans tend to be zealous defenders of private property and limited government), and a businessman openly

1 Arguably, the most well-known instances of expropriation are those that were pushed forward by the Castro government in Cuba, Mugabe, in Zimbabwe, or Chávez, in Venezuela. The skewed view that expropriation is imposed exclusively by socialist governments has regained steam in the US due to the rising popularity of democratic socialism. Consider the following fragments from an article published on the Fox Business webpage: "Twenty years ago, Hugo Chavez started his socialist revolution: he confiscated valuable farm land [...] That's how socialists operate: expropriate. Take. Seize. [...] He nationalized the oil business: his government just took it. Expropriation. [...] socialism is immoral. It is wrong to seize property" (Varney, 2019). These issues (popular perceptions of expropriation, the way the issue is treated in mainstream media) certainly deserve closer analysis; for the purposes of this paper, however, anecdotal evidence will have to suffice. 
defended an expansion of the State's power to expropriate. The hidden assumption, of course, is that it would never be his property subjected to expropriation. This assumption is well-founded: a statistical analysis of expropriations in the US -specifically "for private to private transfers of property for economic development" - shows that targeted areas are "disproportionately populated" by ethnic minorities and people with low incomes (Carpenter \& Ross, 2009, pp. 2455-2456).

The 'taking clause' of the US Constitution, like the laws of other liberal democracies, is alleged to restrict the government's expropriation powers by making them conditional and exceptional. However, the limitation of these powers hinges on the definition of 'public use', which is now defined broadly and vaguely as 'economic development'. In the words of US Supreme Court Judge O'Connor (2005): “Under the banner of economic development, all private property is now vulnerable to being taken and transferred to another private owner" (p. 1). This is not a uniquely US phenomenon. Governments across the world have seized land for investments alleged to foster development - often just a euphemism for economic growth driven by capital accumulation- and many have changed the content or official interpretation of the law to facilitate such takings.

Expropriation, of course, is just one among many forms of dispossession. Dispossession, more broadly, has received renewed attention in the context of the global land rush (Fairbairn, et al., 2014). Much of the recent land grab literature (see e. g., De Schutter, 2011; Deininger, et al., 2011; Abbink, 2011; Wily, 2011; Fairbairn, 2013) focuses on acquisitions for agricultural projects in countries where large segments of the population lack formally recognised rights to their lands, and legal systems are (at least allegedly) particularly weak or corrupt. Dispossession in the global North and in urban settings is rarely mentioned in this literature, and there are good reasons for this, such as the characteristics of the recent land rush ${ }^{2}$ and these scholars' primary concern with agrarian political

2 Starting in the mid to late 2000s, investors took an increasing interest in acquiring large areas of land, primarily for agricultural and commercial forestry projects, especially in Africa and Asia. See, for example, the World Bank's (2011) Rising Global Interest in Farmland, reports by the NGO Grain or the Land Matrix webpage, which offers a platform for exploring data on large-scale land acquisitions. 
economy. Nevertheless, an examination of diverse forms of dispossession -in this case, the expropriation of urban land/homes - can enrich our understanding of the issue and sheds a different light on questions that are central to the land grab debate.

Mainstream explanations of dispossession suggest that it arises in the absence of clearly defined formal property rights and of a strong rule of law (see e. g., Deininger, 2003; Deininger, et al., 2011). As highlighted by Wolford, et al. (2013), it is often assumed that land grabs occur in fragile States and "that improved governance is the key to addressing the most problematic aspects" of this phenomenon (Wolford, et al., 2013, p. 191). This article contributes to a critique of these claims by examining expropriations for economic 'development' in the US, typically deemed (at least in conventional accounts) to have strong private property institutions and a strong rule of law.

The US is a particularly relevant country-case ${ }^{3}$ for this article's purposes. Arguably, property rights have a political and cultural significance in the US that is unparalleled in, for example, European countries. Some commentators suggest this has deep historical roots: "Private property symbolizes the political and ideological beliefs upon which the United States is founded" (Jacobs, 2010). These ideas have a popular echo and are frequently mobilised in political discourse. Consider the following fragments from a speech given by former US Senator (and then presidential candidate) John McCain (2007), precisely in response to the Kelo ruling discussed in this article:

central to our ideals is the sanctity of property rights. Without private property there can be no freedom, and without freedom there can be no America [...] [this] was the motivating force behind our struggle to obtain independence. And in the years after achieving independence,

3 Here, I use the US as an illustrative case; it serves, above all, a rhetorical purpose. I am not trying to suggest that expropriation is equally prevalent in all countries with clearly defined property rights and a forceful legal system. As argued below, the contents of the law and how it is interpreted/applied partly depends upon the balance of power within and between different groups and ongoing political and social struggles. This means that the prevalence and character (e. g., the purposes it is used for) of expropriation will vary between and within countries. My point is that clearly defined property rights and a forceful legal system do not necessarily protect against "legal" forms of dispossession, and the US case illustrates this argument well. 
the Founders ensured that the property rights for which they fought were protected by our Constitution.

The article starts with an introduction to the issue of expropriation, which is typically presented as a conditioned exception to property rights. Then, section 2 presents an overview of the infamous Kelo case. Section three provides a critical analysis of the Supreme Court's decision in Kelo v. New London. The discussion also refers to other relevant eminent domain cases/rulings. On the basis of these sections, I propose that expropriation in the US is neither rigorously conditional nor particularly exceptional. This examination of expropriation in the US calls into question simplistic assumptions about the relationship between dispossession on the one hand, and private property rights and the rule of law on the other.

The fourth section discusses the rule of law concept; because its definitions are contested and slippery, it is difficult to make sense of the claim that land dispossession is due to its weakness. I argue, echoing other authors, that the legal realm is a site of constant struggle and, thus, the relationship between law and land grabbing is not merely a technical issue.

The final section briefly considers some broader conceptual/theoretical issues. Among other points, I indicate the importance of examining how property rights violations ${ }^{4}$ are used to mobilise land for growth driven by capital accumulation (capitalist development), something frequently overlooked even by critical scholars, who commonly focus on privatizations and enclosures or the establishment and expansion of private property.

4 What constitutes a property rights violation is a matter of dispute. For example, some observers argue that "[w]ealth redistribution financed by taxation is a violation of the property rights of taxpayers" (Huemer, 2017, p. 268). The idea that the expropriation of land or buildings constitutes a violation of property rights is relatively less contentious. Nevertheless, given that expropriation, imposed in line with the law, is technically legal, some may argue against this idea. It is not my objective here to argue that expropriations violate property rights in the technical/ legal sense. I use the phrase 'violation of property rights' to contrast expropriations, specifically the taking of land under private title, with other forms of dispossession (e.g., enclosures of common land) that are associated with the imposition and expansion of private property. The question of what constitutes a property rights violation, in legal or philosophical terms, is beyond the scope of this article. 


\section{Expropriation: A Conditioned Exception to Property Rights?}

Legal systems worldwide refer to the State's exclusive 'right' to take private property against the will of its owner -often called eminent domain or taking powers. The process itself is variously referred to as expropriation, appropriation, condemnation, forcible acquisition, or compulsory purchase. To avoid confusion, I use the term expropriation. Most country's taking clauses require (a) that expropriation only be used where the public interest demands it -or variations on this theme, (b) that it follows a legal process, and (c) that the expropriated receive 'just' compensation. These conditions are said to distinguish expropriations under liberal democracy from arbitrary takings by despotic rulers. This article focuses on the first condition (a), which determines "the very scope of eminent domain power" (O'Connor, 2005, p. 4).

Modern takings laws -informed by the liberal notion of rights- are supposed to restrict the State's power; expropriation is presented as an exception to property rules. For example, the 1789 French Declaration of the Rights of Man and the Citizen proclaims: "Since property is an inviolable and sacred right, no one shall be deprived thereof except where public necessity, legally determined, shall clearly demand it, and then only on condition that the owner shall have been previously and equitably indemnified" ${ }^{\prime \prime}$ (Article 17). Similarly, the $5^{\text {th }}$ Amendment of the US Constitution (also from 1789) states: "No person shall be [...] deprived of life, liberty, or property without due process of law; nor shall private property be taken for public use, without just compensation". The public interest 'exception' is also contained in the European Convention on Human Rights (1952): "No one shall be deprived of his possessions except in the public interest and subject to the conditions provided for by law"6 (fragment from Article 1).

Various forms of property may be subject to the government's taking power, from entire companies to patents and trade secrets. Furthermore, lively legal debates on government takings have led to distinctions

5 Emphasis added by the author.

6 Emphasis added by the author. 
between varied types, such as indirect takings, ${ }^{7}$ regulatory takings, ${ }^{8}$ or easement takings. ${ }^{9}$ Many readers will be familiar with the notion of direct expropriation: "A formal transfer of ownership of some asset from a private person or firm to the government, effected at the demand of the government and without regard to the desires of the private person or firm" (Chayes, et al., 2008). While this definition focuses on transfers to the government, eminent domain has increasingly been used to reallocate property rights to private entities. My focus here is on full and direct expropriations of land (and associated homes/buildings) specifically, and, in particular, those cases that favour private investors and are imposed in the name of economic 'development'.

As stated previously, in most countries, governments are -legally- only allowed to expropriate for the public. Some legal texts refer to 'public necessity' (French Declaration of the Rights of Man), others to 'public use' (US 5th Amendment), and others to 'public interest' (European Convention on Human Rights). The difference in wording is noteworthy since one would imagine this would influence the answer to the question: when can eminent domain be used? For example, the words: need and interest imply quite distinct things. But, in contrast to many traditions of legal interpretation, the word choice seems to make little difference.

Many governments have pushed the boundaries of what constitutes an acceptable expropriation, beyond projects of public necessity,

7 This is when a government violates property rights de facto without a formal process. The following is a commonly used example: a government constructs a dam, which floods an adjacent farm, making agriculture on that land unviable. The land has effectively been 'taken' from the farmer, as a result of a specific government action. In the US, this could be deemed a 'functional equivalent' to a 'taking'. This is often called 'inverse condemnation' because the roles are reversed: the affected person initiates the proceedings rather than the government (US Department of Justice, 2015; Chayes et al., 2008).

8 In some instances, regulations more broadly (as opposed to specific actions, as per the definition of 'indirect takings') are also treated as takings (Chayes, et al., 2008); in addition to impacting property use and values, such regulations may even force people to relinquish their land (see e. g., Reason TV, 2011). Some observers argue that any regulation that causes a property to lose value requires compensation. Critics point out, among other things, that this would make almost all environmental policies unviable (Gray, 2013, p. 252).

9 For example, a government may forcibly acquire an easement -land use rights - to allow for example, oil pipelines on privately owned land (Cornell University Law School, 2007a; Gray, 2013, p. 252). Easement takings are different to full and direct expropriations because they do not entail a transfer of ownership. 
use, or even interest. The specifics of this shift (timing and nature) are particular to different countries. However, there is evidence that it is a global trend. For example, Levien (2013) details how by the 1990s "land [in India] was increasingly expropriated for any private purpose that represented a higher-value land use than agriculture - no matter how immaterial, consumptive or speculative" (p. 384). Meanwhile, in a number of African countries, clauses about "public purpose [... were] explicitly expanded in most land laws during the 1990-2010 era to include private investments" (Wily, 2012, p. 768). Similarly, "the Guatemalan Congress passed an eminent domain law in 2010 that would explicitly allow the state to expropriate land on behalf of private companies" (Grandia, 2013, pp. 252-253). And, according to Gray and Porter (2015), "[p]owers of compulsory purchase [i. e., expropriation] for urban planning and redevelopment purposes have been significantly extended under recent planning legislative reforms in England and Scotland" (p. 388).

The subsequent two sections develop the argument that expropriation in the US -alleged bastion of private property rights - is neither rigorously conditional nor particularly exceptional. There are indications this observation applies to other liberal democracies with capitalist market economies (see e. g., Gray \& Porter, 2015; Levien, 2013); though further research is required to support this as a general claim.

\section{The Kelo Case and Beyond: Expropriations for Private Investments}

Though the weakening of constraints on government expropriation powers has a long history in the US (Pritchett, 2003; Werner, 2001), the infamous 2005 Kelo v. New London ruling is widely cited as a milestone in this process (Miceli, 2011, p. xi; Cornell University Law School, 2007a). This section introduces the Kelo case (setting the scene for section 3 , which offers a critical analysis of the legal reasoning in Kelo v. New London) and then briefly considers some of its antecedents.

In January 1998, the State of Connecticut "authorized a \$5.35 million bond issue" to finance the redevelopment of New London. A month later, the pharmaceutical company Pfizer announced plans to 
open a research facility in the town. The New London Development Corporation (NLDC) ${ }^{10}$ was in charge of plans for renewing the waterfront and downtown spaces, and of helping the city "capitalize on the arrival of the Pfizer facility". The plans focused on the Fort Trumbull area and included a conference centre and hotel, parking lot, office buildings, new housing, retail and dining, river walkway, and marina, among other things (Stevens, 2005, pp. 2-3). The city authorised the NLDC to purchase and -if necessary- expropriate properties in order to carry out the redevelopment. The intention was to lease the acquired land to private developers. While the legal battles described below were on-going, "the NLDC was negotiating a 99-year ground lease with the firm] Corcoran Jennison [...] [that] contemplated a nominal rent of $\$ 1$ per year" (Stevens, 2005, p. 13).

Most owners - of the 115 properties the city wanted to tear downsold 'voluntarily'. The quotation marks are deliberately placed since, as one of the city's councillors noted, the mere threat of expropriation is often sufficient to pressure a sale (cited in: Somin, 2015). Many were bullied into selling by various means (Somin, 2015). But nine owners -of 15 properties - resisted. They included, among others: Susette Kelo, who is said to have fallen in love with her "little pink house" (Kelo was designated 'lead plaintiff', hence the naming of the case); Wilhelmina Dery, who had lived in her home since she was born in 1918; and the Cristofaro family, who moved to Fort Trumbull after being forced out of "their previous home [which] had been condemned as part of an[other] urban renewal project" (Somin, 2015).

In 2000, the NLDC initiated expropriation proceedings for the 15 properties it had been unable to acquire through private negotiations. The owners took legal action (with the support of the Institute for Justice) in an attempt to halt the seizures. They argued, among other things, that the taking of their properties for economic development did not meet the 'public use' requirement and was thus an unconstitutional

10 "The NLDC [which the City authorities delegated with eminent domain powers] is a private, nonprofit corporation whose mission is to assist the city council in economic development planning. It is not elected by popular vote, and its directors and employees are privately appointed" (O'Connor, 2005, pp. 2-3). 
abuse of eminent domain (Somin, 2015; Cornell University Law School, 2007b; Stevens, 2005).

In 2002, the New London Superior Court prevented the seizure of 11 buildings, arguing that "the condemnations were not reasonably necessary and that future use of the[se] parcel[s] was uncertain" (Cornell University Law School, 2007b). However, it approved the expropriation of those properties that were to be torn down for the office buildings and parking lot. Both sides appealed. In 2004, the Connecticut Supreme Court approved all 15 of the expropriations. Finally, in 2005, the US Supreme Court agreed to review the 2004 judgement and "to determine whether a city's decision to take property for the purpose of economic development satisfies the public use requirement of the Fifth Amendment" (Stevens, 2005, p. 5). Their answer was yes. The Court ruled -with 5 in favour (or 'concurring') and 4 against (or 'dissenting') that the expropriation of private property for economic development can be considered a constitutional application of eminent domain.

As of 2016, more than ten years after the US Supreme Court ruling, the Fort Trumbull area was a "wasteland". Deals with numerous developers floundered, and, in 2009, Pfizer closed down its research facility in New London, shortly before its generous tax incentives expired. The expropriations failed to stimulate economic development and the promised jobs this was supposed to entail (IF), 2016b; Torres, 2014).

What happened to Susette Kelo and her neighbours was not new, nor was it particularly unusual. In the nineteenth and early twentieth centuries, expropriation powers were "used to support the expansion of the nascent economy" in several parts of the US (Pritchett, 2003, p. 9). For example, in the late 1800s, the Nevada Supreme Court defended the use of eminent domain to favour a mining company, arguing that "all other interests are subservient" to the industry since "the present prosperity of the state is entirely due to the mining developments" (Dayton Gold \& Silver Mining Co v Seawell, 1876, cited in: Stevens, 2005, p. 17). Though "state courts vacillated between support for an expansive use of eminent domain and a fear that condemnation would be abused to the detriment of individual property rights", the US federal Supreme Court "when it considered such matters [...] was generally amenable to the 
use of eminent domain to support economic development" (Pritchett, 2003, pp. 9-11; see also Werner, 2001, pp. 342-343).

In the 1930s, city planners, real estate firms, and politicians formed an alliance to promote urban renewal and eliminate 'blight' -blamed for social problems and economic stagnation- using eminent domain (Pritchett, 2003, pp. 14-21). In 1949, the US government passed the Housing Act, permitting federal money to be given to local authorities to buy up or expropriate 'blighted' properties, which they would then destroy so that the land could be resold to developers, often at a loss (Simon, 2004, p. 142; Pritchett, 2003, pp. 26-36). Some questioned the constitutionality of transferring expropriated lands to private investors. But, in 1954 (Berman v. Parker), the US Supreme Court determined that takings for urban (re)development, including cases where "the land would be leased or sold to private parties" (cited in: Stevens, 2005, p. 11), were constitutional. In the 1950s-1960s, more than a million people were forced from their homes to make way for such urban renewal projects (Pritchett, 2003, p. 47).

The urban renewal concept later lost the widespread support it had enjoyed in the post-war years, but expropriation continued and was/ is often defended as a means of securing job-generating investments (Pritchett, 2003, pp. 48-50). Another oft-cited case is that of Poletown Neighborhood Council v. City of Detroit (1981), in which the Michigan Supreme Court endorsed expropriations for a new General Motors plant. Pritchett (2003) explains: "To keep General Motors from building elsewhere, the city spent over $\$ 200$ million to acquire and prepare the property [displacing more than 4000 people and destroying a racially diverse neighbourhood in the processl, which it sold to the company for $\$ 8$ million [i. e., at a substantial loss]" (pp. 48-49).

The US Institute for Justice, which claims to "defend homes and businesses from government land grabs" (IFJ, 2017), found over 10200 cases "of actual or threatened condemnation [expropriation] for private parties between 1998 through 2002". It is important to note that many people cannot afford the costs of a legal challenge and are forced to sell 
'voluntarily' under the threat of expropriation. ${ }^{11}$ This figure, for just four years, "represents only the tip of the iceberg", since there is no "official database" and many cases "go entirely unreported in public sources" (Berliner, 2003, p. 2).

In short, the 2005 Kelo v. New London ruling endorsed previous legal decisions and the well-established practice of expropriating farmers, homeowners, and small businesses to make way for private investments alleged to foster broader economic development.

\section{The Legal Reasoning: Private Projects as Public Purpose}

As suggested above, it is unclear what is novel about the Kelo case in and of itself. Perhaps the main reason it generated a glut of citations (including my own) is that it was the first major federal us Supreme Court ruling on eminent domain and the meaning of 'public use' specifically, since 1984. Or maybe the key difference, compared to earlier rulings, lies in the explicit use of the term 'economic development'. Either way, the Kelo texts are insightful, as they trace a cumulative loosening of the conditions under which the exercise of eminent domain is permissible. This section draws on the Kelo decision (concurring and dissenting opinions), including reference to earlier legal cases.

The question posed in the 2005 Kelo ruling is whether economic development is a constitutionally valid public use. Underneath this overarching question lies a number of other issues discussed in previous hearings, ultimately dismissed by the Court. The logical order is to ask the main question first, since if the answer to this is no, then all other issues are irrelevant. However, for the sake of structural clarity, I leave the primary point until near the end.

(1) An issue that can arise in court proceedings is whether a given expropriation is necessary in order to achieve the stated public use or purpose (e.g., could the land be acquired elsewhere via voluntary market

11 "A deal struck voluntarily is quite different than a deal struck with someone who says, 'hand it over, or we'll take it by force'. In many ways, the number of threatened uses of eminent domain for private parties tells more than the number that were actually filed" (Berliner, 2003, p. 6). 
exchange instead?). One of the reasons the New London Superior Court prohibited the seizure of some properties in Fort Trumbull was precisely because 'the condemnations were not reasonably necessary' (see above). But the US Supreme Court refused "to second-guess the City's determinations as to what lands it needs to acquire" (Stevens, 2005, p. 12). Analysts from the Institute for Justice argue, more generally, that court rulings in the US have set a precedent in which the government is not obligated to show "that it actually needs the property in question" (IF), 2016a).

(2) Judges may ask whether the 'intended use' of the land 'is sufficiently definite'. The second reason the New London Superior Court provided for denying the seizure of some properties in the City was 'that future use of the parcel was uncertain' (see above). This question is especially relevant where the land is passed into private ownership, or in cases where the long-term lease conditions are vague, barring assurances of the new land use, which allegedly justifies the dispossession (on a similar point see Werner, 2001, p. 344).

(3) Linked to the above, the court may consider how likely it is that the purported public benefits will actually occur. In the 2004 Connecticut Court proceedings, "the three dissenting justices [...] would have found all the takings unconstitutional because the City had failed to adduce 'clear and convincing evidence' that the economic benefits of the plan would in fact come to pass"12 (Stevens, 2005, p. 5). The 2005 ruling made clear that the US Supreme Court did not believe it was responsible for 'judging' the 'efficacy' of a 'development plan'. This is significant given that many people have been forced from their homes, only for the area to be abandoned, causing economic decline rather than prosperity.

Overall, the implication of the Kelo ruling is that government authorities (or the delegated agency) are not legally bound to provide evidence that any given expropriation is necessary, has a clearly defined objective (i.e., certainty regarding the intended use of the land), nor that the alleged public benefits will actually be achieved. The Kelo ruling did not set a precedent in this sense, as earlier judicial decisions had already established the view that "courts are ill-equipped to evaluate the

12 Emphasis added by the author. 
efficacy of proposed legislative initiatives" and to "evaluate whether, in a given case, eminent domain is a necessary means by which to pursue the legislature's ends" (O'Connor, 2005, p. 7; see also Pritchett, 2003; Werner, 2001).

(4) The question inevitably arises as to whether it is acceptable for the State to force a transfer of land from one private party to another. The US Courts established long ago that expropriated land may be passed to private parties when the beneficiary is entrusted with providing a public service. In the Kelo case, the concurring judges acknowledged that the intended land use was not primarily to provide services for the general public. However, they did not rule against the expropriations on the grounds that public use should be understood more broadly as public purpose (in this case, defined principally as the generation of jobs and taxes) and that "the government's pursuit of a public purpose will often benefit individual private parties" (Stevens, 2005, p. 10). Nevertheless, "the sovereign may not take the property of A for the sole purpose of transferring it to another private party B"13 (Stevens, 2005, pp. 5-6, emphasis added). Put simply: the US legal system allows for expropriated land to be passed into private ownership or control, so long as this is not the sole objective. According to the judges' reasoning, no expropriation in favour of a private company could be ruled against as a 'purely private taking', in so far as they all employ people and pay taxes. Put differently: if the promise of new jobs and additional tax revenue is sufficient to constitute a public purpose, then most private enterprises fulfil these criteria. Following that logic, all private for-profit ventures are redefined as projects of public purpose, and practically any private company with enough political clout is an eligible beneficiary of expropriation.

(5) The judges recognise the risk that the government might disguise private interests as public ones: "Nor would the City be allowed to take property under the mere pretext of a public purpose" (Stevens, 2005, p. 6). In the 2004 Kelo case, the plaintiffs argued that the expropriations would primarily "benefit [the] private entities [...] Corcoran Jennison and Pfizer" (Norcott, 2004, p. 27). The Supreme Court justices rejected this view and agreed with the Connecticut judgement, which concluded

13 Emphasis added by the author. 
"there was no evidence of an illegitimate [private] purpose" (Stevens, 2005, p. 6). The validity of a taking essentially boils down to how the authorities justify the expropriation and the official paper trail. So long as the documents reiterate a public interest motive and refrain from disclosing any intention to benefit a particular firm, the expropriation is likely to pass the legal test. ${ }^{14}$

(6) The main question: what is public use? As far back as the nineteenth century, US judges argued that the term 'use' should not be understood literally and opted to replace it with the term 'purpose'. The Kelo ruling states two main rationales for this change: (a) "the 'use by the public' test [was] difficult to administer" and (b) "it proved to be impractical given the diverse and always evolving needs of society" (Stevens, 2005, p. 6). The judges provide a brief example of why it is difficult to establish a test of public use: "What proportion of the public need have access to the property? at what price?" (Stevens, 2005). Suffice to say that the dominant legal opinion would find 'public use' too restrictive even if there were a consistent formula for establishing it. As Stevens (2005) summarises, in the past, US Courts ruled that a variety of aims may qualify as a public purpose. In this case, the City of New London "formulated an economic development plan that it believes will provide appreciable benefits to the community, including -but by no means limited to- new jobs and increased tax revenue" (Stevens, 2005, p. 9). And it is up to regional and local authorities, not the Supreme Court, the judges argue, to determine 'public needs' 15 (Stevens, 2005, p. 10).

The implications are severe. If pubic use, purpose, interest, benefit, or needs are defined as widely and vaguely as 'economic development', then governments can expropriate for practically any project they claim will bring investment to an area and create more monetary value than the current land use standing in its way. In brief, the answer to the question: when can eminent domain be used? is whenever the government sees

14 As argued by dissenting judge O'Connor (2005), the ruling "maintains a role for courts in ferreting out takings whose sole purpose is to bestow a benefit on the private transferee [...]. Whatever the details of Justice Kennedy's undisclosed test, it is difficult to envision anyone but the 'stupid staff[er]' failing it" (p. 10).

15 The dissenting judges are critical of this idea: "An external, judicial check on how the public use requirement is interpreted, however limited, is necessary if this constraint on government power is to retain any meaning" (O'Connor, 2005, p. 5). 
fit, so long as (a) the change in land use is alleged to generate economic development and (b) so long the authorities claim they have the public interest at heart (see O'Connor, 2005). Even before the Kelo ruling, "[l]egal scholars from [diverse] perspectives [...] [had] argue[d] that government powers of eminent domain are practically limitless" (Pritchett, 2003, p. 2; see also Werner, 2001).

(7) The logic of the ruling is inherently biased against certain groups, namely, small businesses and low-income households. On the one hand, it is often assumed (though this is not necessarily the case) that large companies generate more jobs and tax revenues than small businesses. On the other hand, given that property taxes are anchored to value, poor people's homes can easily be razed to make way for luxury apartments (or office buildings, casinos, and factories) on the grounds they will generate more government income. Both dissenting opinions from the Kelo case converge on this issue, as well as the influence of political power on the outcomes:

Any property may now be taken for the benefit of another private party, but the fallout from this decision will not be random. The beneficiaries are likely to be those citizens with disproportionate influence and power in the political process [...]. As for the victims, the government now has license to transfer property from those with fewer resources to those with more (O'Connor, 2005, pp. 12-13).

The consequences of today's decision are not difficult to predict [...] extending the concept of public purpose to encompass any economically beneficial goal guarantees that these losses will fall disproportionately on poor communities [...] [who are] not only systematically less likely to put their lands to the highest and best social use, but are also the least politically powerful (Thomas, 2005, pp. 17-18).

The issue of 'blight' (the word itself is derogatory, denoting disease or infestation) indicates another way in which expropriation in the US is class- and race-biased. In the Kelo case, neither the properties nor the neighbourhood itself was said to have suffered from blight (Stevens, 2005 , p. 4). However, the implicit assumption in the ruling is that it is 
more defensible to expropriate 'blighted' properties. This view is so widely held that some US state laws (e. g., California) only permit expropriations "for economic development purposes in blighted areas" (Stevens, 2005, p. 18). Of course, low-income families are more likely to live in so-called 'blighted' properties "considered less worthy of the full bundle of property rights recognized by American law" (Pritchett, 2003, p. 4). Pritchett (2003) argues, furthermore, that redevelopment schemes -justified using the blight concept- played a key role in perpetuating and deepening "racial segregation" (p. 6). Indeed, in the 1950s/1960s urban renewal came to be seen as synonymous with 'negro removal' (Pritchett, 2003, p. 47; Werner, 2001, p. 351). In the much-cited Berman v. Parker (1954) case, Washington DC authorities deemed an entire neighbourhood to be 'insanitary' and 'unsightly'. But providing inhabitants with subsidies to stimulate repairs or rebuilding was apparently not an option, arguably because the real issue was never the community's living conditions. Some 4500 African American families were forcibly displaced, and the majority could not afford to return: "Of the 5900 new buildings constructed in the area, only 310 were classified as moderately-priced housing units" (Whose Downtown?, 2013; Pritchett, 2003, pp. 46-47).

(8) The harms caused by expropriation apparently have no import from the legal perspective. While the question of benefits (point 3 above) was considered and dismissed as beyond the court's purview, in the concurring judgement the injury, or in economists' terminology 'costs', inflicted by the expropriations did not even arise for dismissal. ${ }^{16}$ Ironically, very few expropriations are subjected to cost-benefit analysis (CBA). Of course, the deficiencies of CBA are boundless, but it is worth highlighting the hypocrisy of an establishment obsessed by this method. The economics discipline has apparently invaded all areas of law and policy, except where you might expect it most: expropriations justified on quintessentially utilitarian grounds.

In conclusion, in light of the Kelo ruling, the idea that contemporary takings law is a limitation on government power starts to wither. The

16 The dissenting judges touch upon the issue of harm by emphasising the social inequity implications. Justice Thomas (2005) also mentions personal injuries: "No compensation is possible for the subjective value of these lands to the individuals displaced and the indignity inflicted by uprooting them from their homes" (p. 17). 
ruling provides legal confirmation of what has long been a reality in practice in the US and in other parts of the world. That this text should come from the US Supreme Court is particularly significant given that the country is typically considered (at least, in conventional accounts) to have a strong rule of law that favours the defence of private property rights in particular.

\section{Tackling Land Grabs in the Global South Via Titling and the Rule of Law?}

As noted above, mainstream explanations of land dispossession -focused on the global South- suggest that it arises in the absence of clearly defined property rights and a strong rule of law. Qualitative evidence does indicate that people without formal statutory rights are more vulnerable to dispossession, effected by the State and private agents, than their counterparts with legal title (see e. g., Deininger, 2003; Wily, 2011, 2012; Velasco, 2014; Fairbairn, et al., 2014; Gutiérrez Sanín E Vargas Reina, 2016). However, this is merely one among many enabling conditions for dispossession, which is neither necessary nor sufficient. Put very simply: even people with property rights over their land/homes have been dispossessed in the US and elsewhere. Given the simplicity of the former point, the remainder of this section focuses on the rule of law component of the argument.

At the most basic level, a country is said to have a 'weak rule of law' if the government is unable/unwilling to enforce legal norms, or itself violates them. A strong rule of law is said to be essential for protecting groups with less power and resources against dispossession since "self-enforcement will be highly correlated with individuals' wealth" (Deininger, 2003 , p. 24). For example, elite landowners are more likely to be able to afford fences and guards to defend their land claims (Deininger, 2003, p. 24). Conversely, powerful and wealthy individuals can act with impunity and take others' land where the rule of law is weak.

However, the rule of law is a contested and slippery concept (Coleman, 2018; Waldron, 2016; Mattei $\&$ Nader, 2008). Some definitions 
are limited to 'formal' and 'procedural' principles that do not determine the content of the law. For example, the law itself should be impersonal, stable, and, thus, predictable, clear and disseminated as public knowledge; an impartial tribunal should be in charge of administering the law; the reasons for its decisions should be based on arguments and evidence, and made available to the affected parties; and the latter have a right to be present and represented at a hearing (incomplete list based on Waldron, 2016). But if the concept is limited to such principles, we must reject the proposition that dispossession occurs due to a weak rule of law because the law itself may sanction it.

Many people simply assume the rule of law comprises the protection of private property. Some actually assert that stable and impersonal property rules are "the essence of the rule of law" (Cass cited in Waldron, 2016). According to Coleman (2018), "a specific vision of the 'rule of law' that has nothing to do with the rights of citizenship and everything to do with property rights" (p. 5) has become predominant in the neoliberal era. Accepting that the defence of private property is part of the rule the law, implies adopting a "substantive" definition (i.e. going beyond the formal and procedural), and this "inaugurates a sort of competition in which everyone clamors to have their favorite political ideal incorporated [...] such as human rights or democracy [...] The upshot is that people struggle to use the same term to express disparate ideals" (Waldron, 2016).

The ambiguity of the rule of law concept, nevertheless, is not resolved by focusing on the protection of private property as its main substantive component. Multiple observers have argued that expropriations for private projects violate the right to property and the requirement that such takings only be used for the public benefit. So, should we conclude that the US, for example, has a weak rule of law? To reiterate: the rule of law concept is contested and slippery, making it difficult to make sense of the claim that land dispossession is due to its weakness.

Furthermore, the rule of law, which under liberal substantive definitions includes the protection of property, is often treated as a technical issue. If dispossession is widespread, then the solution is to change the law or improve impartial enforcement mechanisms: "Legal reform is 
needed where [...] certain categories of users or owners face a high risk of land loss or expropriation" (Deininger, 2003, p. 75). I do not wish to discount the idea that some legal reforms could help protect against dispossession. However, the content of the law and how it is interpreted and applied depends on ideology, the changing balance of power between different (inter and intraclass) groups, and the multiple constraints and pressures faced by the government.

Theoretically, the "Rule of Law is supposed to lift law above politics" (Waldron, 2016), but this is a fantasy. In practice, the legal realm is a site of constant struggle. This is true all over the world, not just in the global South or in countries deemed to have 'fragile' governments. For example, according to the Institute for Justice, "the parties who gain from eminent domain abuse [in the US...] have disproportionate influence in the political arena [...] [and] have fought hard against eminent domain reform" (IFJ, 2010). Furthermore, what changes have been achieved, in some US states, were attained through tireless "grassroots activism" (IF], 2010). To give another example: Pritchett's (2003) historical analysis of the 'blight' concept reveals the different ways elites organised support for urban redevelopment via slum clearance, influencing the interpretation of US law (pp. 51, 14-34). In short, it is not a technical problem. As argued by Mattei and Nader (2008)

[t]he dominant image of the rule of law [...] is false historically and in the present [...] [it] starts from the [erroneous] idea that good law (which others 'lack') is autonomous, separate from society and its institutions, technical, non-political, non-distributive (p. 5).

To clarify, it is not that the content of the laws, the government's ability to enforce them, and the nature of the judicial system do not matter; they do. The problem is fetishizing legal reform and other technical fixes. Policy-oriented researchers who blame dispossession on a weak rule of law often ignore power relations and ideology or treat them as exogenous factors. Borras and Franco (2010) put forward a similar argument in their analysis of the discourses surrounding 'land governance'; they show how policies and programs that are treated as 'technical' and 
'neutral' are, in fact, inherently political. Achieving genuinely "pro-poor" and "democratic land governance", they argue, demands recognition of this fact and then strengthening "autonomous" rural "mobilisations", identifying and supporting allies in government, and ensuring "mutually reinforcing interactions between" them (pp. 23-24).

So, the most obvious implication of the discussion presented above is that the formal recognition of tenure rights plus a strong rule of law (definitional issues momentarily aside) do not protect against all forms of dispossession. This statement may appear to be a truism, but it is often assumed that the problems associated with the global land rush may be resolved by granting titles, improving registers, strengthening governance, and eliminating corruption. Institutions such as the United Nations Food and Agriculture Organisation (FAO) and the World Bank are right to emphasise the vulnerability of people without formally recognised land rights and the role of incompetent or unscrupulous government agents in creating the conditions for certain types of dispossession. However, overall, "portrayals of the state as weak or corrupt and of the need for good governance as a solution to the excesses of expropriation are overly facile" (Wolford, et al., 2013, p. 206).

Titling programs and improvements to the rule of law (imagining, for the sake of argument, we agree on what the latter means and that both 'solutions' can be effectively implemented) are likely to transform rather than 'solve' dispossession. Supposing 'illegal' dispossession (i. e., that without official State sanction) effected by private agents or corrupt government functionaries could be eliminated, we are still left with the question of 'legal' dispossession. And dispossession -with all the attributes of an orderly, efficient, transparent legal process - is still dispossession.

The issue of expropriation is sometimes reduced to the idea that so long as 'just' compensation is paid, it's acceptable. There are two main problems with this view: 1) In the US and elsewhere, the systems used for determining 'just' compensation tend to systematically 'undercompensate' people without power and resources (Berliner, 2003; Cernea, 2004; Levien, 2011; Miceli, 2011; N. Gray \& Porter, 2015). It is worth asking if the dispossessed/displaced were truly 'made whole' would the project for which they were removed remain financially viable, relative 
to the profit prerogatives of the beneficiary firm? Arguably, systematic under-compensation is often an in-built attribute of 'legal' dispossession, not a mere oversight. 2) Non-financial and immaterial losses are ignored, or it is falsely assumed that they can be cancelled out with additional money or the right policies. Because many people value their homes, farms, or territories for non-monetary reasons, dispossession ethics cannot be restricted to compensation.

In sum, the titling/formalisation and the rule of law solutions to land dispossession tend to downplay the importance of power relations, de-politicise inherently ideological questions, and sweep away ethical debates by masking them as technical problems.

\section{From Privatisations and Enclosures to Expropriations of Private Property}

The discussion presented in this article also has implications for the way critical scholars approach the issue of dispossession. Contemporary scholarship on land grabbing largely focuses on the imposition and expansion of property rights or privatisation and enclosure, especially those that draw on Marx's concept of primitive accumulation and Harvey's notion of accumulation by dispossession (a discussion of this issue is provided in Hall, 2013). This makes sense in so far as dispossession linked to these processes is ongoing in many parts of the world. However, the expropriation of private property is also an important form of dispossession, including in the global South (see e. g., Levien, 2011; 2013; Velasco, 2014); the concepts and theories we use to explain and understand dispossession should be refined to reflect this fact.

The terms 'enclosure' and 'expropriation' are sometimes used interchangeably (see e. g., White, Borras Jr., Hall, Scoones \& Wolford, 2012; see also Hall, 2013). Though many dictionaries define 'expropriation' as any unspecified act of dispossession, as explained earlier, the term also has a more specific meaning: the forcible taking of private property by the State. Arguably, the flexible use of dispossession-related vocabulary (with very different connotations) can generate conceptual confusion. 
In the contemporary era, land under private ownership is usually already physically and socially 'enclosed', so it makes little sense to call dispossession achieved through expropriation 'enclosure'. Also, while enclosure often signifies the imposition of exclusionary private property rights over common lands (though there may be exceptions such as the fencing of forests for State-owned conservation areas), expropriation implies a violation of private property rights. Finally, government agencies are central 'actors' in expropriation processes; in contrast, the enclosure of common land can be imposed by private actors with or without official State sanction.

In the most basic sense, from the perspective of the dispossessed and displaced, it does not matter whether the seized land had legal title. Furthermore, the public interest justification is used and abused no matter what type of land-holding is affected. However, the issue is relevant when considering mainstream narratives, which portray a lack of clearly defined property rights as the main problem and formalisation programs (alongside the rule of law) as the central solution.

Some business representatives and mainstream economists suffer from a sort of cognitive dissonance when it comes to State-backed dispossession. On the one hand, they maintain that 'efficient' land allocation and use is best assured through voluntary transactions within a context of free markets and private property rights. On the other hand, they also accept that many investments or 'development' projects could not or would not proceed without coercive land acquisition. Few scholars or policymakers have attempted to address this apparent tension systematically. Arguably, there is reluctance to acknowledge that the capitalist land regime is laden with internal contradictions, and perpetuating growth based on capital accumulation relies on both the imposition and the violation of private property rights in land (see Thomson, 2019). Unfortunately, the role of property rights violations in mobilising land for capital accumulation and economic growth is frequently overlooked even by critical dispossession scholars (Gray \& Porter's 2015 article is a notable exception), ${ }^{17}$ who -as

17 Gray and Porter (2015) advance arguments that are closely aligned with those presented in this article. Drawing on an examination of expropriations for 'urban regeneration' in Glasgow (Scotland), they argue that the "suspension of normal private property rights" is an example of the "normalisation" of the "state of exception". These expropriations are imposed in the name 
noted above- commonly concentrate on the imposition and expansion of private property. This omission is detrimental to a comprehensive understanding of land dispossession, in all its forms.

Consider that numerous governments in the global South are simultaneously attempting to construct capitalist land markets based on a respect for private ownership, while at the same time using their taking powers to violate these newly established property rights. Hence, the ostensible paradox mentioned above - that capitalist economies depend on both the imposition/enforcement and the violation of private property rights - is intensified in contexts where land markets are still under construction. Some governments have understood that private property in land can act as both a driver of and an obstacle to growth and profits; they have, therefore, opted to impose the system partially, excluding some areas from privatisation. State-owned lands allow governments to promote large-scale investments (by leasing or selling large areas of land), which otherwise might have required expropriations, usually implying higher compensation costs and lengthier legal processes. People are often denied titles so that land can easily be mobilised to serve economic growth; they are kept vulnerable to dispossession on purpose (see Thomson, 2019; on the final point see also Wily, 2011).

In sum, the analysis presented in this article not only serves to challenge mainstream discourses on land grabbing in 'developing' countries; it also points to the need for conceptual and theoretical innovation in critical dispossession scholarship focused on the global South.

\section{Conclusion}

The US is conventionally portrayed as a bastion of private property rights. Nevertheless, the evidence presented above indicates that expropriation in the US is neither rigorously conditional nor particularly exceptional. Further research is required to make this a general proposition about liberal democracies with capitalist market economies, but the US

of "the public interest", which "is whatever the state says it is [...] framed within the growth-based economic logic of late capitalism" (Gray \& Porter, 2015, pp. 383, 391 and 393). 
case appears to be symptomatic of a broad global trend. As mentioned earlier, various countries have changed their laws or (re)interpreted existing ones in ways that facilitate 'legal' dispossession for private investments projected to generate more monetary value than the existing land use. The arguments put forward have important corollaries for the way we think about the relationship between property rights, the rule of law, and dispossession.

One of my main objectives in this article was to use cases from the US to shed a different light on land grabs in the global South. Mainstream discourses tend to treat dispossession as a 'developing' country problem blamed on weak and corrupt legal systems and inadequate property institutions. Of course, the contents of a country's laws and the government's willingness and ability to apply them do influence the prevalence and character of dispossession. It is also true that people without formally recognised rights are more vulnerable to coercive land acquisitions. Nevertheless, titling/registration programs and reforms aimed at strengthening the rule of law are likely to transform, rather than solve, the problems surrounding land dispossession. In the cases discussed above, the dispossessed had formally recognised property rights, but the State used its eminent domain powers to override them. Whether or not these expropriations should be attributed to a deteriorating rule of law in the US ultimately depends on how one defines this concept. In any case, the content of the law and how it is interpreted and applied depends on ideology, the balance of power between different groups, and the constraints and pressures faced by the government. Note that many of those involved in grassroots struggles against coercive land acquisitions in the global South are keenly aware that it is a particular economic model (aimed at achieving capital accumulation and growth at almost any cost), which is ultimately at the heart of most contemporary dispossession. They understand that while titles and legal reform may serve them in short-term battles, the true 'solutions' lie elsewhere.

Finally, the discussion in this article has various implications for broader theoretical debates. Orthodox and heterodox scholars alike concur that the establishment/enforcement of private property is essential to capitalist market economies, but very little has been said about the role of expropriations (the direct infringement of these rights) in 
this same socio-economic system. As noted above, critical scholars - for good reasons - have mostly focused on enclosures or the links between land dispossession and the establishment/expansion of modern private property rights. They tend to neglect the fact that, once established, capitalist land markets don't always provide land and resources, in the right places, at the right price - relative, that is, to the demands of capital accumulation and growth-. In this sense, it is time we started adding some new questions and issues to the debates on land grabbing.

\section{References}

Abbink, J. (2011). 'Land to the foreigners': economic, legal, and socio-cultural aspects of new land acquisition schemes in Ethiopia. Journal of Contemporary African Studies, 29(4), 513-535. Doi: https://doi.org/10.1080/02589 001.2011 .603213

ABC News. (2016, February 6). Republican Debate 2016 | GOP New Hampshire Debate on $A B C$ News. Retrieved from https://www.youtube.com/ watch? $\mathrm{v}=\mathrm{bOne} \_$Ler44E

Berliner, D. (2003, April). Public power, private gain. A five-year, state-by-state report examining the abuse of eminent domain. Retrieved from https://ij.org/ report/public-power-private-gain/

Borras, S. M., G Franco, J. C. (2010). Contemporary discourses and contestations around pro-poor land policies and land governance. Journal of Agrarian Change, 10(1), 1-32. Doi: https://doi.org/10.1111/j.1471-0366.2009.00243.x

Carpenter, D. M., E Ross, J. K. (2009). Testing O'Connor and Thomas: does the use of eminent domain target poor and minority communities? Urban Studies, 46(11), 2447-2461. Doi: http://dx.doi.org/10.1177/0042098009342597

Cernea, M. (2004). For a new economics of resettlement: a sociological critique of the compensation principle. International Social Science Journal, 55(175), 37-45. Doi: https://doi.org/10.1111/1468-2451.5501004

Chayes, A., Fisher, W., Horwitz, M., Michelman, F., Minow, M., Nesson, C., \& Rakoff, T. (2008). The bridge: philosophy-takings IA six-unit series on legal reasoningl. Retrieved from http://cyber.law.harvard.edu/bridge/Philosophy/ takings_toc.htm

Coleman, L. M. (2018). Global social fascism: violence, law and twenty-first century plunder. (CGPE Working Paper No. 15). Brighton, UK: University of Sussex. 
Cornell University Law School. (2007a, August 6). Takings. Retrieved from https://www.law.cornell.edu/wex/takings

Cornell University Law School. (2007b, October 18). Kelo v. City of New London, Connecticut (04-108). Retrieved from https://www.law.cornell.edu/ supct/cert/04-108

De Schutter, O. (2011). How not to think of land-grabbing: three critiques of large-scale investments in farmland. The Journal of Peasant Studies, 38(2), 249-279. Doi: https://doi.org/10.1080/03066150.2011.559008

Deininger, K. (2003). Land policies for growth and poverty reduction. Washington D. C.: World Bank Publications-Oxford University Press.

Deininger, K., Byerlee, D., Lindsay, J., Norton, A., Selod, H., E Stickler, M. (2011). Rising global interest in farmland: can it yield sustainable and equitable benefits? Washington: World Bank Publications.

Fairbairn, M. (2013). Indirect dispossession: domestic power imbalances and foreign access to land in Mozambique. Development and Change, 44(2), 335-356. Doi: http://dx.doi.org/10.1111/dech.12013

Fairbairn, M., Fox, J., Isakson, S. R., Levien, M., Peluso, N., Razavi, S., ... Sivaramakrishnan, K. (2014). Introduction: new directions in agrarian political economy. The Journal of Peasant Studies, 41(5), 653-666. Doi: https://doi. org/10.1080/03066150.2014.953490

Fox News. (2015, October 6). Donald Trump on eminent domain: I think it's wonderful. A fragment from Bret Baier's special report extended interview. Retrieved from http://www.foxnews.com/on-air/special-report-bret-baier/blog/2015/10/07/ donald-trump-eminent-domain-i-think-its-wonderful

Grandia, L. (2013). Road mapping: megaprojects and land grabs in the Northern Guatemalan Lowlands. Development and Change, 44(2), 233-259. Doi: https://doi.org/10.1111/dech.12020

Gray, C. B. (2013). The philosophy of law: an encyclopedia. London: Routledge.

Gray, N., E Porter, L. (2015). By any means necessary: urban regeneration and the "state of exception" in Glasgow's Commonwealth Games 2014. Antipode, 47(2), 380-400. Doi: https://doi.org/10.1111/anti.12114

Gutiérrez Sanín, F., E Vargas Reina, J. (2016). Introducción. In F. Gutiérrez Sanín E J. Vargas Reina (Eds.), Quiénes, cómo, por qué. El despojo paramilitar y su variación (pp. 1-40). Bogotá: Editorial Universidad del Rosario.

Hall, D. (2013). Primitive accumulation, accumulation by dispossession and the global land grab. Third World Quarterly, 34(9), 1582-1604. Doi: https://doi. org/10.1080/01436597.2013.843854 
Huemer, M. (2017). Is wealth redistribution a rights violation? In J. Brennan, D. Schmidtz \& B. van der Vossen (Eds.), The Routledge handbook of libertarianism (pp. 259-271). London: Routledge.

IFJ. (2010). Five years after Kelo: the sweeping backlash against one of the supreme court's most despised decisions. Retrieved from https://ij.org/report/ five-years-after-kelo/

IFJ. (2016a). Atlantic city condemnation-Vera Coking. Retrieved from https://ij.org/ case/casino-reinvestment-development-authority-v-coking/

IFJ. (2016b). Kelo Eminent Domain. Retrieved from https://ij.org/case/kelo/

IFJ. (2017). Eminent Domain. Retrieved from https://ij.org/issues/private-property/ eminent-domain/

Jacobs, H. (2010, May). U.S. Private Property Rights in International Perspective. Retrieved from https://www.lincolninst.edu/publications/conference-papers/ us-private-property-rights-international-perspective

Levien, M. (2011). Special economic zones and accumulation by dispossession in India. Journal of Agrarian Change, 11(4), 454-483. Doi: https://doi. org/10.1111/j.1471-0366.2011.00329.x

Levien, M. (2013). Regimes of dispossession: from steel towns to special economic zones. Development and Change, 44(2), 381-407. Doi: http://dx.doi. org/10.1111/dech.12012

Mattei, U., E Nader, L. (2008). Plunder: when the rule of law is illegal. Oxford: Blackwell.

McCain, J. (2007, August 6). McCain's August 6, 2007, speech addressing private property rights. Retrieved form http://edition.cnn.com/2007/POLITICS/12/21/ mccain.trans.privateproperty/

Miceli, T. J. (2011). The economic theory of eminent domain: private property, public use. Cambridge: Cambridge University Press.

Norcott, J. Susette Kelo et al. v. City of New London et al. (SC 16742). (Conneticut Supreme Court 9 March 2004).

NPR. (2016, February 17). Trump opponents try to build property rights into A S.C. primary issue. Retrieved from http://www.npr.org/2016/02/17/467032836/ trump-opponents-try-to-build-eminent-domain-into-a-s-c-primary-issue

O'Connor. Kelo v. New London (O'Connor, J., dissenting). 545 U.S. 469 (U.S. Supreme Court 2005).

Pritchett, W. (2003). The 'public menace' of blight: urban renewal and the private uses of eminent domain. Yale Law \& Policy Review, 21(1).

Reason TV. (2011). Battle for the California desert: why is the government driving folks off their land? Retrieved from https://www.youtube.com/watch?v=yw3RiMdS7sE 
Simon, B. (2004). Boardwalk of dreams Atlantic City and the fate of urban America. New York: Oxford University Press.

Somin, I. (2015, May 29). The story behind Kelo v. City of New London - how an obscure takings case got to the Supreme Court and shocked the nation. Washington Post. Retrieved from https://www.washingtonpost.com/news/ volokh-conspiracy/wp/2015/05/29/the-story-behind-the-kelo-case-how-anobscure-takings-case-came-to-shock-the-conscience-of-the-nation/

Stevens. Kelo v. New London (Opinion of the Court). 545 U.S. 469 (U.S. Supreme Court 2005).

Thomas. Kelo v. New London (Thomas, J. dissenting). 545 U.S. 469 (U.S. Supreme Court 2005).

Thomson, F. (2019). The political economy of land and dispossession in Colombia. (PhD Thesis, University of Sussex). Retrieved from http://sro.sussex.ac.uk/ $\mathrm{id} /$ eprint/84599/

Torres, A. (2014, February 5). Nine years after Kelo, the seized land is empty. National Review Online. Retrieved from http://www.nationalreview.com/ article/370441/nine-years-after-kelo-seized-land-empty-alec-torres

US Department of Justice. (2015, May 12). The world of inverse condemnation. The United States Department of Justice. Retrieved from https://www.justice. gov/enrd/world-inverse-condemnation

Varney, S. (2019, January 24). Venezuela crisis: socialism is immoral, never prospers. Retrieved from https://www.foxbusiness.com/politics/ venezuela-crisis-socialism-is-immoral-never-prospers-varney-says

Velasco, J. D. (2014). Negociando la tierra: empresas extranjeras, minería a gran escala y derechos humanos en Colombia. Estudios Socio-Jurídicos, 16(1), 285310. Doi: http://dx.doi.org/10.12804/esj 16.1.2014.07

Waldron, J. (2016). The rule of law. In E. N. Zalta (Ed.), The Stanford encyclopedia of philosophy. Retrieved from https://plato.stanford.edu/archives/fall2016/ entries/rule-of-law/

Werner, D. (2001). The public use clause, common sense and takings. Boston University Public Interest Law Journal, 10, 335-359.

White, B., Borras Jr., S. M., Hall, R., Scoones, I., E Wolford, W. (2012). The new enclosures: critical perspectives on corporate land deals. Journal of Peasant Studies, 39(3-4), 619-647. Doi: https://doi.org/10.1080/03066150.2012. 691879

Whose Downtown? (2013, May 17). Urban renewal: the story of Southwest D.C. Retrieved from https://whosedowntown.wordpress.com/ urban-renewal-the-story-of-southwest-d-c/ 
Wily, L. A. (2011). 'The law is to blame': the vulnerable status of common property rights in Sub-Saharan Africa. Development and Change, 42(3), 733-757. Doi: https://doi.org/10.1111/j.1467-7660.2011.01712.x

Wily, L. A. (2012). Looking back to see forward: the legal niceties of land theft in land rushes. Journal of Peasant Studies, 39(3-4), 751-775. Doi: https://doi. org/10.1080/03066150.2012.674033

Wolford, W., Borras, S. M., Hall, R., Scoones, I., \& White, B. (2013). Governing global land deals: the role of the state in the rush for land. Development and Change, 44(2), 189-210. Doi: https://doi.org/10.1111/dech.12017 